\title{
Kobieta żydowska, kobieta czytająca
}

Magdalena Rzadkowolska 


\section{Magdalena Rzadkowolska}

\section{Kobieta żydowska, kobieta czytająca}

Każdego dnia pobożni Żydzi w modlitwie porannej wypowiadają słowa:

Pochwalony Ty, Wiekuisty Boże nasz, Królı Wszechświata, który nie uczyniłeś mnie kobieta!.

Kobiety zaś odczytują ze swoich modlitewnikíw:

Bądź blogostawiony, Boże nasz, królı świata, zal to, żeś mnie stworzył wedle swojej woli².

Wedtug rabinicznych interpretacji mężczyźni nie czynią tego, by okazać swoją pogardę, ale dlatego, ze kobieta ma mniej micu'ot (religijnych obowiązków) do przestrzegania. Najgodniejsze zachowywanie przepisów religijnych: 248 nakazów i 365 zakazów, jest dążeniem każdego bogobojnego Żyda. Natomiast kobiety obowiązują tylko trzy reguły: zapalania i błogosławienia świec w szabasowy wieczór, oczyszczenia w mykwie po menstruacji i dzielenia chaty.

W rodzinie żydowskiej wychowanie dziewcząt różnilo się od wychowania chłopców. Chociaż

w wieku dziecięcym nie można zauważyć wielkiej różnicy mię̧dzy w odnoszenin się do chłopców i dziewcząt, jednakże rodzice cale swe nadzieje po-

' D. Lifschitz, Z mądrości dhas\}'dow'. Kiclec 1998, s. 30.

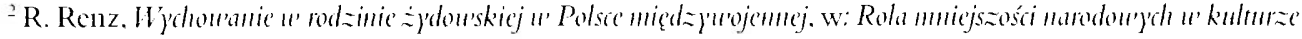

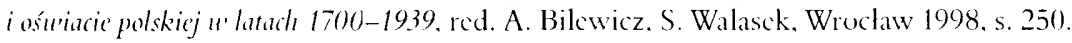


kladają w synach. W uroczystościach rodzinnych i świętach biorą dziewczęta udział tylko pośredni, gdyż na pierwszym planie występują tylko chłopcy ${ }^{3}$.

Kobieta żydowska jawi się jako osoba skromna, cicha, milcząca, pracowita, posłuszna mężowi, dbająca o rodzinę. Niewiasta realizująca zalecania religijne, z których wiele dotyczy prowadzenia domu.

Żyd miał nie tylko prawo, ale również obowiązek studiować święte księgi. Uczony był otaczany szczególnym szacumkiem. 1)latego też żydowski ojciec, zwłaszcza zamożny, starał się wydać swoje córki za mąż. nawet za człowieka ubogiego, ale takiego który poświęca się studiowaniu Tory' i Talımıdı. Zwyczajowo opiekowal się młodym małzeństwem, a zwlaszcza wspierał je finansowo, nawet przez dlugi okres czasu, by zięć nógł przygotować się do objęcia funkcji rabina.

Ciężar prowadzenia i utrzymania donu spadal na kobietę. Musiała być dobrym administratorem, potrafiącym stworzyć mężczyźnie warunki, by mógł poświęcić się zgłębianiu wiedzy religijnej. W tym celı bardzo często podejmowała różne prace zarobkowe. Zdobywała środki na utrzymanie domu, gdy mąż zajęty od świtu do nocy stıdiowaniem świętych i uczonych ksiąg, dysputami religijnymi, przesiadywal w jeszybocie lub bet-hamdraszu. Talmudyści opuszczali swoje rodziny, by wędrować całymi miesiącami z miasta do miasta i poznawać slawnych rabinów.

Żony pobożnych Żydów często portretowała literatura pozytywizmu. Bohaterka opowiadania Elizy Orzeszkowej Siln' Samson Cipa prowadziła mały sklepik korzenny. Skromny dochód, jaki uzyskiwała, musiał wystarczyć na potrzeby siedmioosobowej rodziny.

Ażeby zashużyć sic̨ publiczności i zdobyć od czasu do czasu jakiś grosz naddatkowy, staje się ona wszystkim na przemian: poshańcem publicznym, pośredniczką między pożyczającymi a chcącymi pożyczać, sprzedającymi a chcącymi nabywać. W sklepie siaduje dorywczo tylko, od czasu do czasu; wyręcza ją tam matka, z sióstr która, sąsiadka jaka; ona zaś sama biega całymi dniami ze wschodów na wschody, dźwiga pod ramieniem ciężkie zawinięcia, nosi na plecach stosy starej odziezzy, staje pokornie u progów różnych z dwoma koszami w rękach, z których jeden zawiera bakalie, a drugi herbatę i butelki z winem, kłóci się z kucharkami i stróżami domów, którzy ją do dobrodziejów puszczać nie chą, przekupuje surowość ich parą fig albo garsteczką orzechów; niekiedy wpada w niecierpliwość z osobami płci swojej. które wytwarzają dla niej uciążliwą konkurencję, zawodzi na ulicy takie kłótnie, iz zblizają się ku niej stróżowie porządku publicznego $(. .)^{+}$.

W Torze nie ma jasno sformulowanego zakazu studiowania jej przez kobiety. Natomiast w Talımudzic znajduje się podstawa tego powszechnie obowiązującego prawa.

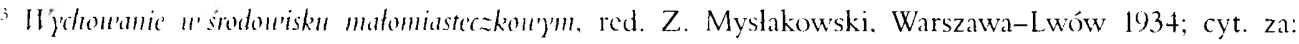

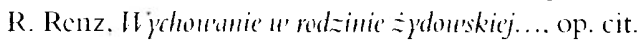

+ E. Orzeszkowa, Silmy Sumson. cyt. za: eadem, Z jednego strumienia. Nowele. Warszawa 1960), s. 30(0)-301.
} 
Pewien nauczyciel oświadczyl: „Człowiek ma obowiązek wyuczyć córkę Tory”. Ale zaraz po tym padlo stwierdzenie wręcz przeciwne: „Kto uczy swą córkę Tory, to jakby uczyl ją tiflut". Inny rabin twierdzil: "Nicch stowa Tory rzucone zostaną raczej na pastwę ognia, niżby miały być przekazane niewiastom" "5.

Uważano, że kobiecie nie jest potrzebna wiedza, bo jej przeznaczeniem jest wyjść za mąż, musi podobać się mężowi, a Bogn i tak się spodoba. Julian Stryjkowski w powieści Głosy" "ciemmości przedstawił postać Pesi, córki rabina z Głogowa, która czytała religijne księgi, jak Mojre Neu'ichim. Jej młodsza siostra Surałe, która uważa, że żydowski mąż nie potrzebuje uczonej żony, powie o niej:

Ramabam na pewno nie ma spokoju tan w grobie, odkąd ty się wzięłaś do Mojre Neurichim. Ty moja uczona głowo! Rabinacki mózg! Nie lubię ja kobiet, które pchają się, gdzie nie potrzeba!n.

Talmud jako kobiety wielkiej mądrości i wiedzy wymienia Rachelę, zonç Rabbiego Akiwy, i Berurię, żonę Rabbiego Meira. W tradycji chasydzkiej imiona kobiet czasami są wymieniane obok imion ich męzów czy synów, znanych talmudystów, kabalistów, cadyków. Jak imię Malke, żony Szaloma Rokeacha, zalożyciela dynastii Bełz, która tysiąc dıi i nocy trzymała świecę nad Tora, by mąż mógł studiować. Jej ojciec, który utrzymywal młode małżeństwo, nie pozwalał rebe jeździć do chasydzkiego mistrza, Jasnowidzącego z Lublina. Oddana żona wiązala prześcieradla i pomagala mężowi wykradać się przez okno.

Kobiety żydowskie odbierały wyksztakenie w węższym zakresie niż mężczyźni. Choć teoretycznie nic nie stalo na przeszkodzie, by dorównywaly mężczyznom lub ich przewyższaly: „kobieta jest inteligentniejsza od mężczyzny”. Nie uczyły się w szkolach religijnych i nie znały języka hebrajskiego, używanego w liturgii i piśmiennictwie religijnym, w którym powstały najstarsze teksty judaizmu: Dekalog, Tora, Biblia, Miszua. Zamożne rodziny zatruduiały nauczyciela z chederu, by uczył ich córki, i wówczas mogły poznać nie tylko język żydowski, ale również hebrajski. Żydówki unicjące czytać sięgały po książki napisane w języku jidysz. Uważano, że powstaly w XII wicku na bazie dialektu dolnoniemieckiego, wchłaniający zapożyczenia między innymi z języka hebrajskicgo, język żydowski był whaściwy, by tworzyć w nim książki dla kobiet. W odróżnieniu od hebrajskiego był uważany za mowę gminu. W calej historii Żydów hebrajski uznawano za język święty, uważano, że mistyki liter i słów hebrajskich nie można odtworzyć w żadnym innym języku:

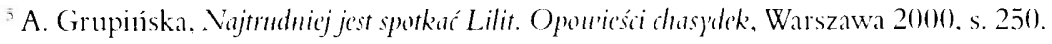

'J. Stryjkowski, (itosy' "cicmmosci. Warszawa 1963, s. 132, 134-135.

Nida t5. cyt. za: K. Gebert. Rodzima, w: $\dot{Z}^{\prime} d=i$ " Polsce. Dzicje i kultura. Leksjken, red. I. Tomaszewski, A. Żbikowski, Warszawa 2001, s. 395.
} 
Co napisano po hebrajsku, wiele traci, wyrażone w obcym języku. Nawet prawo i proroctwa, jako też inne księgi zgoła inaczej brzmią czytane we własnym językư'.

W średniowieczu nie bylo oryginalnej literatury w języku jidysz, dla czytelniczek przygotowywano zapożyczenia z literatury niemieckiej lub włoskiej. Żydzi zamieszkujący tereny niemieckojęzyczne rozumieli język niemiecki, ale nie potrafili odczytać lacińskich liter. Wśród nich rozpowszechniło się przepisywanie, lub pisanie pod dyktando, przez kopistów literami hebrajskimi tekstów niemieckich. Jednym z takich utworów jest Dukus Horant, hebrajska transkrypcja poetyckiej opowieści, zaliczanej do nurtu literatury dworskiej, o księciu imieniem Horant, zawarty w rękopiśmiennym Kodeksie z Cambridge z 1382 roku.

W okresie od XIV do XVIII wieku powstawały liczne wersje literackich tekstów niemieckich, przepisywane ręcznie lub drukowane alfabetem hebrajskim, przeznaczone dla czytelników whadających jidysz. Istnieje wiele wzmianck o utworach, które nie dotrwały do czasów współczesnych, zaginęly lub krążyły wśród Żydów w przekazach ustnych, jak na przykład pieśń na cześć soboty autorstwa rabina Zelmele z Erfurtu, oparta na niemieckiej pieśni Herzog Ernst". W tekstach tych unikano wszelkich pojęć czy imion związanych z Kościolem katolickim, wiarą i religią chrześcijańską, zastępując je terminami neutralnymi.

Adaptowano też włoskie opowieści rycerskie. W przeciwieństwie do transkrypcji z języka niemieckiego, różniły się one od pierwowzoru i w znacznym stopniu były utworami oryginalnymi. Jedno z zachowanych dzieł to pochodząca z 1507 roku powieść włoska Bova d'Antona, w przeróbce na jidysz, dokonancj przez Eliego Lewitę, Bove Duch ${ }^{11}$.

Inspiracji literackich szukano również w Starym Testamencie. Na źródlach biblijnych zostal oparty poemat o Józefie synu Jakuba, Prau'y Jakub, zawarty w Kodeksie z Cambridge. Pochodzące z tego same źródla opowiadanie o Abrahamie, Aırohom ouvinu, zawiera anegdotę o jego ojcu Terachu, która wywodzi się z Beszit Raba, komentarza do Księgi Genezis. Twórczość literacka w języku jidysz powstała w XVI-XVII w. wykorzystywała większość fabularnych wątków zawartych w Starym Testannencie. Pierwszym dziełem były dwie części Księgi

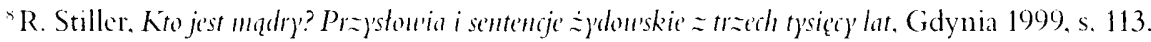

"Por. Ch. Shmeruk, Historia literatury jidy'sz. Wroclaw 1992, s. 25, 26.

"Por. Ch. Shmeruk, op. cit., s. 31, 32. - 1)huga opowieść o losach królcwicza Bovy, który uciekł przed zaplanowanym przez matkę zabójstwem, przcżywał liczne przygody w Europie i na Bliskim Wschodzic, aby w końcu szczęśliwic wrócić do swojego królestwa i zasiąść na tronic, w wersji jidysz zostala skrócona. E. Lewita usumąl lub skrócil opisy nieprawdopodobnych perypetii bohatera, stonowal rubaszną erotykę, zaś zwroty i pojęcia związance z wiarą clırześcijańska zastąpil religijnym sformułowaniami żydowskimi. Judaizacja utworu nic jest pehna. a krzyżowanie siẹ clementów kultury dworskiç i żydowskicj dajc komiczne efekty. l'owicść ta. jak podaje Ch. Shnncruk. byla popularna jeszcze na początkuXIX w., zostala też przethumaczona na wspólczesny jidysz przez Mojzesza Knapheisa i miala dwa wydania: w 1962 i 1970 rokı1. Istnicje równiez jej rosyjska wersja pod tytulem Boru korole'ticz jej reckopis zostal spisany na Bialorusi w drugiej polowic XVI w. Porównanic wersji żydowskicj z rosyjskį wskazuje, iz dotarła ona do Europy Wschodniç za pośrednictwem języka jidysz. 
Sammela przetworzone na jidysz przez kwestarza z Jerozolimy Mosze Dwadzieścia Cztery, który swój przydomek zawdzięczal doskonałej znajomości 24 ksiąg biblijnych. Literaturze jidysz przyswojono Księgi Króleu'skic, Ksiegge Jozuego, Sędzióu, Danicla, Hioba i inne"

WXV wieku zaczęły w jidysz powstawać pieśni religijne śpiewane podczas szabasu i świąt; były to zarówno przeklady tekstów hebrajskich, jak i utwory oryginalne. Z 1534 roku pochodzi pierwsza drukowana w języku jidysz książa zawierająca zbiór przepisów prawa dla kobiet zestawiony przez rabina Szera ben Anszela, która wyszla spod pras krakowskiej oficyny braci I Ialiczów. Wraz z rozpowszechnieniem się w XVI wieku mistyki kabalistycznej do liturgii dolączono modlitwy-prośby tedines, przeznaczone do odmawiania poza synagoga, mające charakter próśb o pomyślność, powodzenie dla męża w interesach, urodzenie dziecka etc. Ich teksty w jidysz były drukowane na kartkach lub w większych zbiorach.

Kobiety miały wpływ na rozwój piśmiennictwa żydowskiego, jedną z nich była Sara córka Tuwima, autorka techim. Na uwage zasługuje twórczość literacka żyjącej w XVI wieku Riwki (Rebeki) Tiktiner córki Majera, rabina z Tykocina. Ta wykształcona, znająca język hebrajski i studiująca Torę autorka nie tylko pisała pieśni śpiewane przez Żydówki podczas święta Simchat Tora - uroczystego dnia, w którym obchodzi się zakończenie rocznego cyklu czytania Tory - ale również przygotowała dla nich traktat o wychowaniu dzieci i obowiązkach kobiet Meneket Rin'k'a.

Jedna z najpopularniejszych książek w języku żydowskim Cene ureene zostala napisana przez pochodzącego z Janowa Lubelskiego Jaakowa ben Icchaka Aszkenazego i wydana po raz pierwszy w 1622 roku. Zawiera, wybrane specjalnie dla kobiet, fragmenty pochodzące z Biblii i Talmudu, wzbogacone poradami i wskazówkami. Do dziś jest znana w środowiskach żydowskich na całym świecie dzięki przekladom na hebrajski i angielski. W ten sposób zostaly wyparte nie tylko literackie zapożyczenia, ale również epika biblijna.

Zwolennicy Haskali, żydowskiego oświecenia, które rozpoczęło się w końcu XVIII wieku, propagowali odrodzenie spoleczności żydowskiej przez rozwój oświaty i nauki świeckiej, dostosowanie jej obyczajów i kultury do nieżydowskiego otoczenia. Podnoszono konieczność znajomości języków europejskich, a przede wszystkim polskiego. Pojawialy się żądania tworzenia dla dzieci żydowskich szkół z wykładowym językiem polskim, usunięcia jidysz i hebrajskiego z życia publicznego, aż do uzależnienia prawa do obywatelstwa od znajomości polskiego. Badacze dziejów Żydów polskich Rafał Żebrowski i Zofia Borzymińska zwracają uwagę, iz do czasu odzyskania przez Polskę niepodległości w 1918 roku wielu Żydów było poliglotami z racji otrzymanego wyksztalcenia, zakorzenionych wzorców kulturowych i z konieczności kontaktowania się z władzami i miejscową ludnością. Także lektury mialy istotny wpływ na proces asymilacji. Jak pisze Joanna Olczak-Ronikier w tomie wspomnień $W$ ogrodzie pamięci, w bawialni jej prababki w 1888 roku pojawila się bibliotecz-

"Por. Ch. Shmeruk, op. cit., s. 23. 37, 40. 
ka - szafka z dziełami zebranymi Mickiewicza, Słowackiego, Krasińskiego, wydanymi przez Brockhausa w Lipsku, w serii Biblioteka Klasyków Polskich. Otrzymał ją ,trzynastoletni Ludwik Iorowitz z okazji bar micwy od wuja, który sam nie najlepiej jeszcze mówił po polsku" "2 . Zaś ze zbiorów korzystaly jego siostry.

W XIX wieku, w ortodoksyjnych rodzinach żydowskich, broniących się przed wpływami Haskali, dziewczętom nie było wolno uczestniczyć w zorganizowanej edukacji. Zamożni chasydzcy ojcowie przyjnowali dla swych córek guwernantki lub nauczycielki. Najczęściej uczono je muzyki, języka polskiego i języków obcych. Postępowi Żydzi pozwalali swoim córkom „chodzić do "gojowskiej” szkoły, czytać książki, tańczyć i bawić sięe"

W przeciwieństwie do chlopców, którym zabraniano studiowania literatury niereligijnej, dziewczęta miały dużą swobodę doboru lektur ${ }^{1+}$ - jak Dinełe, córka reb Chaima Altera, bohaterka powieści Israela J. Singera Bracia Aszkenazy, która

mając niespelna trzynaście lat, naczytała się już dużo niemieckich i francuskich powieści o hrabiach, książętach i baronach, o pojedynkach i romantycznych milościach ${ }^{15}$.

Kobiety pobożne, jak Batszewa, matka pisarza Isaaca Bashevisa Singera, sięgały po książki moralizatorskie, jak Bicz Bo jy czy Księga przymierza - antologię uzupełnioną naukowymi faktami. Czyniły tak, bo ortodoksyjni rabini uważali, że wszyscy pisarze to bezbożnicy, kłancy i szydercy, a ich pisma są obrazą boską. Utożsamiali literata z meszumed, człowickiem, który wyrzekl się swojej wiary. Świeckic książki nazywali słodką trucizną, która wiedzic ludzi do herezji i ufali jedynie świętym księgom ${ }^{16}$.

Na początku XX wicku w większych miastach zaczęto zakładać pierwsze żydowskie szkoły żeńskie. W 1917 roku Sara Szenirer, córka chasydzkiego kupca z Bełza, zalożyła w Krakowie szkołę Beit Jakow. W przedwojennej Polsce uczono w niej przede wszystkim przedmiotów judaistycznych: prawa żydowskiego, liturgii, psalmów. Program uzupełnialy podstawy przedmiotów świcckich. W 1924 roku w kraju uczylo się 2 tys. uczennic w 19 szkolach. Z biegiem czasu ich liczba wzrastała, w 1938 wynosila 38 tys. uczennic w 250 szkolach rozsianych na terenie calej Rzeczypospolitej. W 1925 roku zalożono seminarium nauczycielskie Beit Jakow. W 1922 powstała syjonistyczna Tarbut, syjonistyczne szkoły $\mathrm{CiSzO}$ z wykładowym językiem żydowskim czy religijno-syjonistyczna Jawne.

\footnotetext{
12 J. Olczak-Ronikicr. It ogrodzic pamięci. Kraków 2001. s. 39.

1: I. J. Singer. Bracia .4szkenaz). t. 1. Warszama 1992, s. 70.

${ }^{1+}$ Por. A. Grupińska, Najmudnicj jest spotká Lilit..., op. cit., s. 83; R. Zebrowski, Z. Borzymińska, Po-lin.

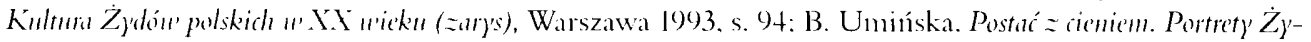

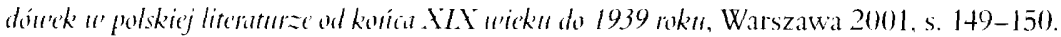

10 I. J. Singer, Bracia . As zkenaz) .... op. cit. s. $60-61$.

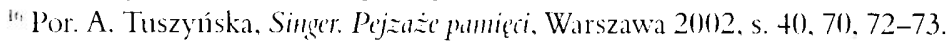


W dwudziestoleciu międzywojennym mastapil wzrost znaczenia języka polskiego dla kultury żydowskiej. Rosnące znaczenie kultury polskiej wynikało przede wszystkim z korzystania, w coraz wiçkszym stopniu, przez żydowskie dzieci, nie tylko wywodzące się z rodzin zasymilowanych, z polskich instytucji edukacyjnych. Zgodnie z wprowadzonymi wówczas reformanini, wszystkie dzieci w wieku od 7 do 13 lat podlegaty obowiązkowi szkolnemu, zaś władze państwa były zobowiązane do finansowania szkół publicznych dla mnicjszości narodowych. Zgodnie z przepisami Ministerstwa Wyznań Religijnych i Oświecenia Publicznego z 1923 roku, w szkołach i oddziałach przeznaczonych dla dzieci żydowskich obowiązywał ten sam program nanczania co w szkołach dla dzieci polskich. Językiem wykładowym był polski, a prócz przedmiotów świeckich dzieci żydowskie były zobowiązane do nauki religii mojzeszowej. Anka Grupiniska w swojej reporterskiej opowieści Najtrudnicj jest spotkać Lilit, opisującej świat religijnych Żydówek, podaje, że w II Rzeczypospolitej okoto 80 procent żydowskich dzieci uczyło się w bezpłatnych szkołach państwowych, głównie podstawowych, bowiem szkolnictwo średnie było nieobowiązkowe. Jedna z jej bohaterek wspomina, że mimo iż pochodziła z rodziny chasydzkicj, to przed II wojną światową uczyła się w polskiej szkole przyklasztornej w Biclsku-Bialej.

Regina Renz zwraca uwagę, iż uczęszczające do państwowych szkól powszechnych młode Żydówki zwykle dobrze się uczyły. Większość z nich kończyła edukację na tym poziomie: dziewczęta zostawały w domu, pomagały matce i oczekiwaly na zamążpójście. Te, które pochodziły z ubogich rodzin, najczęściej pracowały jako służące, kucharki, pokojówki. W tych miejscowościach, gdzie były szkoły średnie, uczęszczały do nich także żydowskie uczennice. Podejmowały także studia na wyższych uczelniach. Z badaí Jadwigi Suchmiel wynika, że do roku 1917/1918 na Uniwersytecie Jagiellońskim studentki żydowskie stanowiły 56,1 procent wszystkich kobiet studiujących na Wydziale Lekarskim i 22,3 procent wśród studentek Wydziahu Filozoficznego. Większość absolwentek pochodziła z ośrodków miejskich, były wśród nich córki kupców, nauczycieli, urzędników, fabrykantów ${ }^{17}$.

Absolwentka szkoły polskiej, żydowskiej, jak i mloda kobieta, która odebrała edukację domową, była przygotowana do kontaktu z lekturą. W książce Grupińskiej jedna z rozmówczyń, wspominając dzieciństwo spędzone w Polsce, opowiada o swojej matce, córce rabina z Otwocka, która chętnie czytała literaturę polską: „Ona bardzo lubila język polski i dużo czytała. Pamiętam ją z książką w ręku albo na kolanach" "s' Nasuwa się pytanie: po jaką lekturę mogły sięgać w okresie dwudziestolecia międzywojennego polskie Żydówki?

We wspomnieniach ocalatych z I Iolocaustu, we fragmentach opisujących ich życie przed wybuchem II wojny światowej, pojawiają się wzmianki o książkach. Łodzianka Emanuela Cunge wiele czasu poświęcała na czytanie książek:

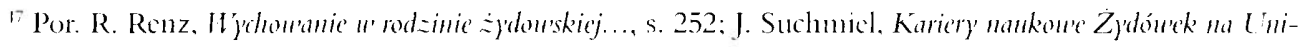

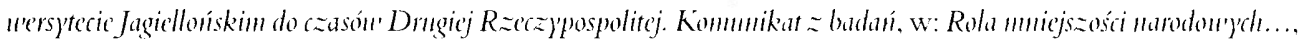
op. cit.. s. 155. 157-158.

${ }^{1 *}$ A. Grupińska, Najtrudnicj jest spotkać Lilit.... s. 190.
} 
Te lata trzydzieste były niezwykle obfite we wspólczesną literaturę piękną, a trzy wielkie księgarnie łódzkie: Gebethnera i Wolffa, Fiszera i Seipelta sprowadzały bez trudu książki autorów obcych, miały przy tym na miejscu wielki wybór dzieł polskich. Lubiłam od dawna te wizyty w księgarniach, z których wychodziłam objuczona książkami ${ }^{19}$.

Ze wspomnień Alexa, dziś ponad siedemdziesięcioletniego informatyka mieszkającego w Bostonie, spisanych przez Joannę Wiszniewicz ${ }^{20}$, możemy się dowiedzieć, że jego matka, wywodząca się z tradycyjnej rodziny żydowskiej, ukończyla szkołę żydowską, jednak mówila i czytała tylko po polsku. Dobrze znała polską literaturę, a jej ulubionym pisarzami byli Bolesław Prus i Stefan Żeromski.

Pierwsze żydowskie biblioteki świeckie zaczęly powstawać w końcu XIX wieku na terenie Galicji, we Lwowie i Krakowie. W Królestwie Kongresowym sieć książnic organizowano po rewolucji 1905 roku, gdy wladze carskie zlagodziły swoją politykę. Dopiero w II Rzeczypospolitej warunki sprzyjały rozwojowi żydowskiego bibliotekarstwa. Większość placówek była utrzymywana ze środków stowarzyszeń i organizacji. Rozwijały się dynamicznie; w 1929 roku w miastach i miasteczkach działało 600 zarejestrowanych bibliotek, które oferowały czytelnikom zarówno klasykę jak i nowości. Minçły juz czasy, w których czytanie świeckich książek uchodzilo wśród Żydów za grzech. Dwudziestolecie międzywojenne to czas rozkwitu literatury żydowskiej, która tworzono po hebrajsku, w jidysz i po polsku. Autorzy starali się

dostarczać kolejne tomy zagorzalym czytelnikom, którzy szukali w literaturze odbicia swego zmieniającego się świata i refleksji poświęconych jego przemianom²1.

W większości bibliotek znajdıjących się w miastach o czytelnictwie i frekwencji decydowały kobiety, które chciały czytać modne powieści. Chętnic zapisywały się do bibliotek publicznych, w których wydawnictwa w języku polskim, przede wszystkim literatura popularna, stanowily około 70 procent księgozbioru. Takie ukształtowanie księgozbiorów sprawiało, że wykraczały poza obszar tematów żydowskich. Dla tych czytelniczek, które nie znały języka polskiego albo znały go słabo, pozostawały przekłady. Z języka niemieckiego thumaczył między innymi Isaak Bashevis Singer, „prawdopodobnie posługując się również polskimi wersjami, Na zachodzie bez zmian Remarque’a, Czarodziejską górę Manna, prozę D’Annunzia, I Jamsuna, Zweiga. Z hebrajskiego przelożył zbiór opowiadań Mojżesza Smilanskiego"ユ2 . Na jidysz przethumaczono prawie cała klasykę, więc chętne mogły

${ }^{16}$ E. C.unge, Ciéc przed Holocanstem, Lódź 1997. s. 37.

2" Zob. J. Wisznicwicz. A jednak azasem micu'am sm). Warszawa 1999

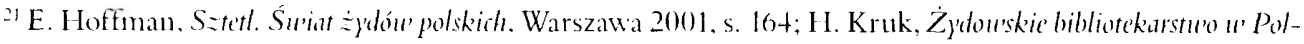
sce. .. Przegląd Biblioteczny“ 8 (193t) $11 \% 1$.

$\geq$ A. Tuszyniska. Singer.... op. cit., s. 142. 
czytać Lwa Tołstoja, Fiodora Dostojewskiego, Iwana Turgieniewa, Marka Twaina czy Juliusza Verne’a.

Należy zwrócić uwagę, iż we wszystkich typach bibliotek w mnicjszości pozostawała literatura żydowska. Znajdowały się w nich popularne prace o twórczości narodowych pisarzy żydowskich, szkice krytyczne o wybranych dziełach, biografie, opracowania historyczne. Wybór literatury pięknej był niewielki, dzieła M. M. Sforima, A. Mapu, S. Alejchema. Natomiast współczesna literatura żydowska była znana jedynie wąskiemu kręgowi odbiorców. Za to czytelniczki odkrywaly autorów pochodzenia żydowskiego, którzy pisali po polsku, na przykład Brunona Schulza, i podziwiały jego opowiadania ukazujące metafizyczną wizję sztetl.

Źródlem bardziej szczególowych informacji o preferencjach czytelniczych będą wyniki badań, jakie w lutym 1932 roku przeprowadził w środowisku bibliotek publicznych i wypożyczalni platnych Krakowa Maksymilian Józef Ziomek. Placówki te skupiały głównie inteligencję pracującą, studentów i uczniów szkół średnich.

Wówczas przebadano 2 tysiące wybranych losowo kart czytelników pięciu krakowskich wypożyczalni: „Czytelni Naukowej i Beletrystycznej” (CNB) - 1 tysiąc, oraz po 250 z Katolickiego Związku Polek (KZP) - skupiającej glownie inteligencje zawodową, Biblioteki Literackiej (BL) - kola handlowe, Towarzystwa Szkoły Ludowej (TSL) - młodzież, i Towarzystwa Uniwersytetu Robotniczego (TUR) - robotników ${ }^{23}$. Popularność pisarza mierzono liczbą osób czytających jego dzieła oraz ilością tomów przeczytanych powieści bez względu na to, ilı czytelników je wypożyczato.

Na uwage zasługują upodobania czytelnicze abonentów biblioteki I3L. Pozwolą one zasygnalizować, jakich wyborów dokonywały osoby wyznania mojzeszowego. W badanej grupie czytelników było 175 kobiet i 75 mężczyzn. Czytelniczki to przede wszystkim osoby bierne zawodowo: mężatki i panny pozostające na utrzymaniu rodziców, które zazwyczaj wypożyczaly 5 książek miesięcznie. Abonentki BL najchętnicj sięgaly po książki pisarzy obcych: Jacoba Wassermana, Ethel M. Dell. Theodore Dreisera, Johna Galsworthy'ego, Uptona Sinclaira, Szaloma Asza. Na zestawionej przez M. J. Ziomka liście 25 najpoczytniejszych w tej wypożyczalni pisarzy jest pięciu Polaków. To: Tadeusz Boy-Żeleński, który znalazł

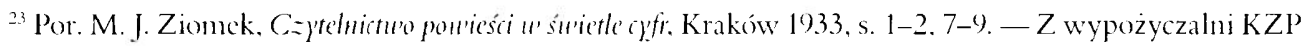
korzystaly glównic kobicty. TUR - mężzzyźni; w innych proporcje plci ukladaly siç nicjednolicic. Co do wyznania, to KZP skupial wylącznic katolików. w TSL równicz byli oni licznic reprezcntowani. podobnic jak w CNB i mnicjszym stopniu w TUR, natomiast BL - czytelników wyznania mojzeszowego. Kobiety częścicj niż mężczyźni zapisywaly się do wypożyczalni i dlatego stanowily $2 / 3$ badancj populacji. Uwzględniając kryterium zawodowe, 1/3 badanych stanowila intcligencja zawodowa imlodzicż, przeważnic nczniowie szkól średnich i studenci. Najslabicj byli reprezentowani robotnicy i rzennieślnicy. zaś $1 / 5$ stanowily osoby bierne zawodowo, na przyklad mężatki i panny na wydaniu. Jak obliczyl Zionck, badani przeczytali lącznic ponad 15 tysiçcy tomów powieści. Wypożyczyli książi autorstwa okolo 1 tysiąca powieściopisarzy. wraz z równie clę̧tnie czytywanymi pracanni. pióra miçdzy innymi Tadeusza Żeleńskiego i Stanislawa Wasylewskiego. 
się w pierwszej dziesiątce ulubionych autorów (pozycja 5. wedtug ilości wypożyczonych tomów; 7. według liczby czytelników), Irena Zarzycka (odpowiednio poz. 15. i 9.), Leo Belmont (poz. 21 wedlug ilości wypożyczonych tomów), Wanda Łuczyńska (poz. 23. według liczby czytelników), Antoni Marczyński (poz. 14. i 24). Należy podkreślić, iż byli to pisarze czytywani dobrowolnie, ich ksiązki nie należaly do kanonu lektur szkolnych.

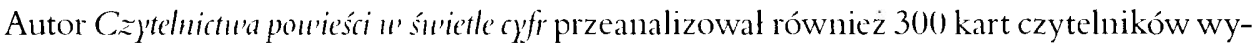
pożyczających książki w lutym 1932 roku z „Żydowskiej Biblioteki Ludowej” w Samborze. W badanej grupie były 182 kobiety i 118 mężczyzn. Osoby wyznania mojżeszowego stanowiły trzy czwarte wypożyczających. Dane dostarczone przez tę placówkę informują o czytelnictwie wśród Żydówek. Najliczniejszą grupę czytelniczek stanowily kobiety między 21. a 30. rokiem życia: żony przy mężach, bierne zawodowo lıb pomagające w pracy mężom, wdowy, panny przy rodzicach. Zazwyczaj wypożyczały 6 do 10 książek miesięcznie.

Podobnie jak w BL w Krakowie, abonentki „Żydowskiej Biblioteki Ludowej” najchętniej wypożyczaly powieści autorów obcych: Jacoba Wassermana, Michela Zevaco, Uptona Sinclaira. Z polskich pisarzy poczytnością cieszyli się Leo Belmont, Maria Rodziewiczówna, Antoni Marczyński i Stefan Żeromski.

Przeprowadzone przez M.J. Zionka badania pokazują, że wśród wywodzących się z mniejszości żydowskiej czytelniczek, które korzystały z wypożyczalni zarobkowych, dużym zainteresowaniem cieszyła się obcojęzyczna literatura wspólczesna. Sięgały najchętniej po powieści obyczajowe, nie zawsze autorstwa wybitnych pisarzy, za to o zajmującej fabule. W oparciu o przeprowadzane wówczas badania poczytności można sformulować opinię, że popularność poszczególnych autorów byla krótkotrwała, ale pozostawalo zainteresowanie poszczególnymi rodzajani literackimi. Wypożyczano powieści przygodowe, sensacyjne i sentymentalne.

Czytelniczki wyznania mojżeszowego w dwudziestoleciu międzywojennym chętnie wypożyczały książki ,modnych autorów”. Jeśli powieść im nie odpowiadała, lub gdy pojawiła się inna nowość, nie wracały już do jego twórczości. Wybierały powieść wspólczesną, traktując literaturę nie tylko jako źródło wiedzy, ale również jako formę rozrywki. Ponieważ pragnęły nadążać za trendami obowiązującymi w literaturze europejskiej, chętnie sięgały po przekłady z języków obcych.

Kobieta żydowska trwała przy swoim mężu i dbała o rodzinę. Posiadała także własne zainteresowania. In lepiej była wykształcona, tym większy wkład wnosiła w rozwój religii i kultury swojego narodu, nie tylko jako żona i matka pobożnych mężczyzn. Także poprzez whasną twórczość i aktywność, jak Sara córka Tuwima, Riwka Tiktiner czy Sara Szenirer.

Ponieważ musiała zapewnić swojej rodzinie środki do życia, miala więcej kontaktów ze światem wartości nieżydowskich i niereligijnych niż mężczyzna. Dzięki temu była bardziej otwarta na nowe idee. Kobieta wywodząca się z kultury, w której zawsze była obecna książka, szukała stosownych dla siebie lektur. Wraz z postępującą asymilacją i coraz lepszą znajomościajjęzyka polskiego zaczęła sięgać po książki polskie. W wyszukiwaniu lektur starała się kierować smakiem i unikać przypadkowych wyborów. 